\title{
Lung Cancer pN2 TNM Finding v8
}

National Cancer Institute

\section{Source}

National Cancer Institute. Lung Cancer pN2 TNM Finding v8. NCI Thesaurus. Code C136462.

Lung cancer with metastasis in ipsilateral mediastinal and/or subcarinal lymph node(s).

(from AJCC 8th Ed.) 